\title{
Pain Threshold
}

National Cancer Institute

\section{Source}

National Cancer Institute. Pain Threshold. NCI Thesaurus. Code C21085.

The minimum level of stimulation of a body part that a person will perceive as being noxious or unpleasant. (Taber's) 